\title{
THE 'CELESTINA' IN FRENCH BIBLIOGRAPHICAL AND ENCYCLOPEDIC WORKS OF THE SEVENTEENTH AND EIGHTEENTH CENTURIES
}

\author{
Denis Drysdall \\ University of Waikato
}

Adrien Baillet, Jugemens des Sçavans sur les principaux ouvrages des Auteurs (Paris: A. Desallier, 1685-6), III, 75-7, article 1231 bis. Baillet's article is the first of only three in this period to show evidence of a personal acquaintance with the Celestina, and is used by many of the subsequent compilers.

\section{RODRIGUEZ COTA.}

(Rodericus Cotta) Poëte Espagnol, sumommé El Tio, c'est-à-dire, l'Oncle, pour le distinguer d'un autre du même nom que l'on ne connoit plus, vivant au commencement du 16. siécle.*

C'est ce Cota que les Critiques font Auteur de la fameuse piéce Espagnole, appellée La Celestine, qui est une Tragi-Comédie de Caliste \& de Melibée. Gaspard Barthius Allemand, mais grand amateur des Livres Espagnols a traduit cet Ouvrage en Latin, \& la [sic, for "l'a"] publié sous le titre énergique de Pornobosco-didascale. Ce Traducteur que nous avons déja dépeint ailleurs, comme un Critique plein de tendresse \& de bonne opinion pour les Auteurs sur lesquels il a travaillé, ne fait point difficulté de diret que cet Ouvrage Espagnol est un Livre tout-à-fait Divin. C'est une espece de jeu comique, rempli de Sentences, d'avis moraux, d'exemples \& de figures très-propres pour instruire le Lecteur, \& ce qu'il y a de remarquable, c'est que la Langue Espagnole a un avantage tout particulier sur les autres pour les Ouvrages de Morale, \& celuy-ci est un des mieux écrits en cette Langue au jugement du mesme Auteur, qui dans une Dissertation \& dans un petit Commentaire qu'il y a fait, s'étend 
fort au long sur les avantages que la lecture de cette piéce peut produire à ceux qui voudront régler la conduite de leur vie.

Il dit que tout y contribuë merveilleuseme[n]t à faire produire ces bons effets; que le style de la piéce est bien travaillé, poli, exacte, nombreux, grave \& majestueux; qu'on y remarque une habileté \& une prudence toute particuliére à bien garder les caractéres \& les mœurs de ses personnages; \& que si on l'en veut croire, nous n'avons rien dans ce que les Grecs \& les Latins nous ont laissé qui en approche; de sorte que les Espagnols ont grande raison de compter cet Ouvrage parmi les meilleures productions de leur pays.

Voilà quel est le jugement de Barthius, qui malgré toute la solidité qu'il pourroit avoir, ne doit pas nous empêcher de nous tenir dans des précautions suffisantes pour la lecture de la Célestine.

On en a fait une Traduction Françoise imprimée plus d'une fois. Elle est de Jacques de Lavardin du Plessis Bourrot [in-8. Paris 1578.] mais elle ne contribuë pas beaucoup à conserver en nous la haute idée que Barthius a voulu nous donner de cet Ouvrage [dans le livre qui a pour titre Porno-bosco-didascalus; seu Celestina Latine cum Comm. per Gasp. Barthium in-8. Francof. 1624.]

Bernard de la Monnoye added two footnotes at the marked points to the Amsterdam, 1725, edition of this work.

* On doit le croire plus ancien, puisqu'on doute qui de Jean Mena ou de lui [Cota] est Auteur de la Célestine, piece constamment du 15. siécle. Elle étoit déja fort connuë en France du tems de Marot qui a dit dans son

2. Coc-à-l'âne:

Or ça le livre de Flammette,

Formosum Pastor, Célestine,

Tout cela est bonne doctrine,

Et n'y a rien de défendu.

Où l'on voit qu'il parle de la Célestine comme d'un Ouvrage aussi commun parmi les gens du monde que le Formosum pastor de Virgile, \& la Flammette de Bocace. Agrippa en donne la même idée chap. 64. de vanitat. Scient. où il fait cette énumération de quelques livres dont la lecture pouvoit être dangereuse, Lancelloti, par exemple, Tristanni (c'est ainsi qu'il faut lire) Eurealis (il devoit dire Euryali) Pelegrini, Calisti $\mathcal{E}$ similium. Endroit qui paroit copié d'après Vivès livre 1. de sa femme Chrétienne. ... Enfin Calisti désigne la Célestine, parce que Caliste amant 
de Melibée est le principal acteur de la Comédie Espagnole intitulée Celestina. Bosco-Did.

+ Gaspar Barthius Dissert. \& Comment. in Tragicomœd. PornoEt ex eo Nicol. Antonius tom. 2. Biblioth. Hispan. pag. 212. 213. ${ }^{1}$

In the Nouvelles de la République des Lettres of February, 1687, Pierre Bayle published a review of Baillet's book, which repeats in brief Barthius's and Baillet's opinion of the Celestina. ${ }^{2}$ For his article on Barthius in his Dictionnaire historique et critique (Rotterdam: A. Leers, 1697), I, 487, note F, Bayle took from Baillet only the attribution to Cota.

Louis Moreri, Grand Dictionnaire historique (Lyon: D. Thierry, 1691), vol. I, "COTA (RODRIGUEZ)". This is the sixth edition of the dictionary, the first to contain a reference to the Celestina. At the end of his article, which consists of a few lines taken from Nicolas Antonio, Moreri refers, not to Barthius's Pornoboscodidascalus but to his Adversariorum commentariorum libri $L X .^{3}$ This gives no bibliographical information or general commentary and contains only a few explanations of classical allusions.

Supplément au Grand Dictionnaire de Moreri (Amsterdam: P. Brunel, 1716), vol. I. Reproduces, almost word for word, Baillet's article. The two articles are combined in the 1759 edition.

Nouveau Dictionnaire historique portatif. Par une société de gens de lettres. [L.-M. Chardon, P. J. Grosley, and F. Moysant] (Amsterdam: M.-M. Rey, 1769), I, 625-6. Also reproduces Baillet's article.

Louis Adrien du Perron de Castera, Extraits de plusieurs pièces du théatre espagnol (Paris: veuve Pissot, 1738), p. 4. The second critic with a personal knowledge of the work. He has rigid neo-classical criteria and little sympathy for the Spanish theatre.

${ }^{1}$ Nicolas Antonio, Bibliotheca Hispana ... (Rome: A. Tinassii, 1672), II, 211-2.

${ }^{2}$ In $C$ uvres diverses de M. Pierre Bayle (The Hague: P. Husson, 1725), I, 757, février 1687, article VII.

${ }^{3}$ Frankfurt: Aubrios and Schleichium, 1624, lib. LVI, ch. VIII; vol. II, col. 26422644. 
Pour les Tragédies, les Espagnols n'en font point; car on ne sçauroit donner justement ce titre à quelques-uns de leurs Ouvrages, qui le portent sans le mériter; telles sont la Celestina \& l'Ingénieuse Helene, qui ne peuvent passer tout au plus que pour des Romans en dialogue.

Le père Niceron, an article on Barthius in Mémoires pour servir à l'histoire des hommes illustres (Paris: Briasson, 1729-45), VII, 21-3. The third writer to show evidence of a personal reading of the work, he has particular formal and moral criticisms, and takes up the question of its religious propriety which had been raised by the expurgations of 1632 .

Pornoboscodidascalus latinus de Lenonum, Lenarum, Conciliatricum, servitiorum dolis, veneficiis \& machinis plusquam Diabolicis ex lingua Hispanica in Latinam transcriptus. Francofurti 1624. in $8^{\circ}$. La piece Espagnole que Barthius a traduite sous ce titre est intitulée en Espagnol la Celestine [sic], \& l'Auteur est Rodriguez Cota. La passion qu'il avoit pour la Langue Espagnole, lui a fait trouver excellente cette Tragi-Comedie. Il en fait l'éloge comme d'un ouvrage accompli, \& va jusqu'à lui donner le titre de livre tou-à-fait divin. Il s'étend même fort au long sur les avantages que sa lecture peut procurer à ceux qui veulent mener une vie reglée. Mais tous ces éloges n'ont aucun fondement. Il n'y a ni ordre, ni intrigues, ni unité dans la piece, les vingt-un actes qui la composent doivent renfermer un espace de tems très-considerable. On n'y trouve que des maximes plus dignes de gens perdus de débauche, que de personnes raisonnables. La Religion d'ailleurs n'y est gueres menagée. Qui pourra par exemple entendre sans indignation faire cette priere à Calixte, qui envoie Sempronio son valet chercher une vieille femme pour corrompre celle dont il a fait sa maîtresse. Dieu éternel \& tout puissant, qui êtes le conducteur des égarez, qui avez conduit à Betlehem trois Rois d'Orient, par le moyen d'une étoile, $\mathcal{E}$ qui les avez ramenez dans leur pays, je vous prie de servir de guide à mon Sempronio, afin que ma peine $\mathcal{E}$ ma tristesse soit changée en joie, $\mathcal{E}$ de donner, encore que $j^{\prime}$ en sois indigne, une bonne issue à mes desirs.

L'abbé Goujet, "Des Traductions des Poëtes Espagnols et Portugais," in his Bibliothèque françoise ou Histoire de la Littérature françoise (Paris: P.-J. Mariette and H. L. Guerin, 1741-56), VIII, 152-92 at pp. 162 and 165-7. His account is borrowed entirely from Du Perron de Castera and La Monnoye. 
David Clément, Bibliothèque Curieuse historique et critique (Göttingen: J. Guillaume Schmid, 1750-69), II, 462-6. Quotes a passage from Barthius's commentary and declares that Niceron's judgement "mérite d'être consulté".

L'abbé Salier, ed., Catalogue des Livres Imprimés de la Bibliothèque $d u$ Roy (Paris: Imprimerie Royale, 1750), Belles Lettres, I, 584, nos 6310-3. No 6310 is the important Comedia, correctly cited as such, of Stanislao Polono, 1501.

La Monnoye, in a footnote to the article on Jacques de Lavardin in the Rigoley de Juvigny edition of the Bibliothèques françoises de la Croix du Maine et du Verdier (1772), I, 422."

La première Traduction de cette Tragicomédie, sans nom d'Auteur, étoit connue dès le commencement du seizième siècle, car je suis persuadé que Marot, qui, dans son second Coq-à-l'âne, fait en 1536, ne la connoissoit que par une version Françoise qui en couroit avant celle de Jacques Lavardin. Voir la note sur l'Art. 1231 de Baillet, Tom. IV.

There is a further note, by M. Falconnet:

Cette pièce, intitulée Caliste $\&$ Mélibée, ou plus communément la Célestine, avoit été composée en Espagnol par le Bachelier Fernand de Rojas.

Maupoint, Bibliothèque des Théatres (Paris: J. Chardon et Briasson, 1733), p. 325. This work, and all the following, contain purely bibliographical notices, often incorrect.

Le chevalier Gordon de Percel [pseudonym of N. Lenglet de Fresnoy], De l'usage des romans ... avec une bibliothèque des romans (Amsterdam: De Poilras, 1734), II, 322-3.

P. F. G. de Beauchamps, Recherches sur les Théatres de France (Paris: Prault, 1735), Deuxième Partie, pp. 46-7.

4 Two bibliographies first published in the sixteenth century. See my "Allusions to the Celestina in works written or published in France up to 1644," Celestinesca 20.1-2 (1996): 21-36. 
[A. de Léris], Dictionnaire portatif des Théatres (Paris: C. A. Jombert, 1754), p. 75.

Le chevalier de Mouhy, "Journal du Théâtre françois," vols I and II (BN. ms. Fonds français, 9229-30 [1752-80?]), under the dates 1527, 1578,1598 and 1633. Believed there were two distinct plays, "Caliste et Mélibée" and "la Celestine", and imagined theatrical performances.

Le duc de la Vallière, Bibliothèque du Théatre françois (Dresden: $N$. Groell, 1768), III, 253-4.

Of all these authorities, only three appear to have any direct acquaintance with the Celestina; of these, only Du Perron de Castera probably read it in Spanish. The other two, the sources for most of the rest, read it in the Latin of Gaspar Barthius (Baillet also in French); and they all disagree with his enthusiastic endorsement of the work. The few useful remarks that emerge seem to support the view that the classical and neo-classical period could not stomach what they judged to be its formal irregularity and its moral licence.

A new current of Celestina criticism was inaugurated by Luis José Velázquez de Velasco in his Orígenes de la poesía castellana (Málaga: Martínez de Aguilar, 1754), pp. 97-100. This work was translated into German by Johann Andreas Dieze, ${ }^{5}$ and augmented with notes from, among others, Antonio, Baillet and Goujet. Dieze, in turn, was used in 1804 by Friedrich Bouterwek, whose work ${ }^{6}$ was published in French in 1812 as Histoire de la Littérature espagnole (Paris: Renard and Michaud frères), the account of the Celestina being in vol. I, pp. 197-203. The fifth volume of the first edition of the Biographie universelle by the frères Michaud, containing an article on Cota and quoting Velázquez de Velasco extensively, is of 1813.

${ }^{5}$ Geschichte der Spanischen Dichtkunst (Göttingen: V. Bossiegel, 1769). See J.-A. Bertrand, "Figures d'Hispanologues. Dieze. Bouterwek," Bulletin hispanique 24 (1922), 343-60.

${ }^{6}$ Geschichte der spanischen Poesie und Beredsamkeit (Göttingen: J. F. Röwer, 1804). For the Celestina, see p. 131. 